\title{
Antigenic differences among aquareoviruses correlate with previously established genogroups
}

\author{
C. P. Dopazo*, I. Bandín, C. Rivas, C. Cepeda, J. L. Barja \\ Departamento de Microbioloxía e Parasitoloxía, Facultade de Bioloxía, Universidade de Santiago de Compostela, \\ E-15706 Santiago de Compostela, Spain
}

\begin{abstract}
Five aquareoviruses, selected to include 1 from each of the 5 genogroups established by Lupiani et al. (1993; Virology 197:475-479), were compared by cross-neutralization and immunodot test procedures. Serological ratios by cross-neutralization were extremely high, demonstrating that the 5 selected strains correspond to 5 different serogroups. On the other hand, the ratios obtained from cross-immunodot test were much lower, and in some cases under 20. Results demonstrate that the serogroups determined by crossneutralization correlate with the previously established genogroups of aquareoviruses.
\end{abstract}

KEY WORDS: Serogroups · Neutralization · Aquareovirus

Over the last $15 \mathrm{yr}$, aquareoviruses have been increasingly isolated from different aquatic animals in different geographic areas. These isolates share several biochemical and biophysical characteristics, but are different in other respects. Few attempts have been undertaken to clarify the taxonomic status of the strains included in the genus Aquareovirus. Serological heterogeneity among several reoviruses isolated from aquatic animals was observed by some authors employing neutralization tests (Hedrick et al. 1984, Ahne \& Kölbl 1987, Brady \& Plumb 1988). Dopazo et al. (1992), studying serological relationships among 5 aquareovirus strains by means of cross-neutralization, immunodot and ELISAs (enzyme-linked immunosorbent assays), established the existence of at least 2 different serogroups among aquareoviruses which correlated with differences in genome electropherotypes. These studies, however, were based on the comparison of few viral strains which limited the significance of the results. Recently, Lupiani et al. (1993) reported the comparison of most of the aquareovirus isolates known at that time (19 strains) on the basis of their RNA pro-

·E-mail:mpdopazo@usc.es files and cross RNA-RNA hybridizations. Based on their results, 5 different genogroups (named $A, B, C$, $D$, and $E$ ) have been established within the genus Aquareovirus.

In the present study, viral strains belonging to each of the 5 genogroups were compared by seroneutralization and immunodot techniques, in order to determine if genogroups and serogroups are correlated.

Materials and methods. The aquareovirus strains used in the present study are listed in Table 1 . Chinook salmon embryo cells (CHSE-214) grown at $15^{\circ} \mathrm{C}$ were used for the replication of all the isolates, except the strain from catfish (CRV) which was grown in channel catfish ovary cells (CCO) at $23^{\circ} \mathrm{C}$. The cells were cultured in Eagle's minimum essential medium (EMEM), supplemented with $10 \%$ foetal bovine serum (FBS) and antibiotics (100 $\mathrm{IU} \mathrm{ml} \mathrm{ml}^{-1}$ penicillin, $100 \mu \mathrm{g} \mathrm{ml}^{-1}$ streptomycin and $50 \mu \mathrm{g} \mathrm{ml}^{-1}$ gentamicin).

Viral isolates were inoculated at an MOI (multiplicity of infection) of 0.1 and when cytopathic effects (CPE) were extensive cells were scraped into the medium and the cell debris pelleted at $3000 \times g$ for $20 \mathrm{~min}$. The supernatant was transferred to a sterile bottle and polyethylene glycol (PEG, molecular weight 8000) added to a final concentration of $10 \%$. The pellet was resuspended in $10 \mathrm{ml}$ of $\mathrm{SSC}$ buffer $(0.15 \mathrm{M}$ sodium chloride, $0.015 \mathrm{M}$ sodium citrate, $\mathrm{pH} 7.2$ ), vigorously shaken for $5 \mathrm{~min}$, centrifuged at $3000 \times \mathrm{g}$ for $10 \mathrm{~min}$ and the supernatant transferred to the former PEG suspension. After incubating overnight at $4^{\circ} \mathrm{C}$ on an orbital shaker, the fluid was centrifuged at $10000 \times \mathrm{g}$ for $30 \mathrm{~min}$ and the pellet resuspended in $10 \mathrm{ml}$ of SSC. An equal volume of Freon was added to the suspension and the mixture was vigorously shaken for $5 \mathrm{~min}$. The resultant emulsion was separated into the Freon and aqueous phase by centrifugation at $8000 \times g$ for $30 \mathrm{~min}$, and the aqueous phase was then centrifuged at 85000 
Table 1. Aquareovirus strains employed

\begin{tabular}{|cllc|}
\hline Genogroup & \multicolumn{1}{c}{ Viral strain } & \multicolumn{1}{c|}{ Species } & Location \\
\hline A & Striped bass reovirus (SBR) & Morone saxatilis & USA \\
B & Simpson coho salmon (SCS) & Oncorhynchus kisutch & USA \\
C & Golden shiner virus (GSV) & Notemigonus crisoleucas & USA \\
D & Catfish reovirus (CRV) & Ictalurus punctatus & USA \\
E & Turbot reovirus (TRV) & Scophthalmus maximus & Spain \\
aGenogroups as established by Lupiani et al. (1993) & \\
\hline
\end{tabular}

tions were mixed (1:1). After $1 \mathrm{~h}$ incubation at room temperature, $0.1 \mathrm{ml}$ of each mixture were inoculated in triplicate wells of confluent cells in 48-well plates. The plates were sealed and incubated at $15^{\circ} \mathrm{C}$ for the CHSE-214 cells, or $23^{\circ} \mathrm{C}$ for the $\mathrm{CCO}$ cells, for a maximum period of $3 \mathrm{wk}$. The neutralizing antibody titers were calculated according to the Reed \& Müench (1938) method and expressed as the $\times g$ for $90 \mathrm{~min}$. The pellet was resuspended in $0.5 \mathrm{ml}$ of SSC, sonicated for $30 \mathrm{~s}$, layered on a 10 to $50 \%$ sucrose gradient and centrifuged at $150000 \times \mathrm{g}$ for $90 \mathrm{~min}$. The visible virus band was collected, concentrated by centrifugation $(85000 \times g$ for $90 \mathrm{~min})$, resuspended in $500 \mu \mathrm{l}$ of buffer and centrifuged for a second time on a sucrose gradient as above indicated. The visible band was finally concentrated at $85000 \times g$ for $90 \mathrm{~min}$, and used.

The 5 antisera were obtained by inoculating young New Zealand white rabbits with purified virus according the following schedule: $100 \mu \mathrm{l}$ of purified virus (approximately $10^{10} \mathrm{TCID}_{50} \mathrm{ml}^{-1}$ ) was diluted (1/5) in phosphate buffered saline (PBS), mixed with an equal volume of complete Freund's adjuvant and injected intramuscularly into each hind leg of the rabbit, and subcutaneously (2 aliquots). One month later, $1 \mathrm{ml}$ of purified virus diluted in a solution of $\mathrm{Al}(\mathrm{OH})_{2}$ was inoculated by intramuscular injection. Two months after the first injection, a last injection was made intramuscularly with purified virus diluted in PBS, and 1 wk later the rabbits were bled. The sera were inactivated $\left(56^{\circ} \mathrm{C}, 30 \mathrm{~min}\right)$ and stored at $-20^{\circ} \mathrm{C}$ until used. Prior to the first immunization, sera from the rabbits were tested and found to be negative for neutralizing antibodies against the 5 aquareoviruses.

The seroneutralization test was performed following the constant virusvarying antiserum dilution method (Okamoto et al. 1983). The viruses were diluted in EMEM without FBS to obtain a suspension containing approximately $10^{3} \mathrm{TCID}_{50} \mathrm{ml}^{-1}$ (initial viral titers ranging from $10^{6.5}$ to $10^{8}$ $\mathrm{TCID}_{50} \mathrm{ml}^{-1}$ ). The antisera were diluted from $1 / 10$ to $1 / 100000$ in EMEM, and viruses and antisera diluthe virus resuspended in SSC and stored at $4^{\circ} \mathrm{C}$ until reciprocal of the highest dilution of the antiserum protecting $50 \%$ of the inoculated cells.

The immunodot assay was performed as previously described (Dopazo et al. 1992). Briefly, pieces of nitrocellulose membrane (HA, $0.45 \mu \mathrm{m}$, Millipore) were washed with PBS and dried under warm air before use. Then, $10 \mu \mathrm{l}$ of crude virus (non-purified tissue culture supernatants, with an approximate titer of $10^{7} \mathrm{TCID}_{50}$ $\mathrm{ml}^{-1}$ ) was added to the membranes and allowed to dry for 15 min at room temperature. Infectious pancreatic necrosis (IPN) virus, EMEM with 5 and $10 \%$ FBS and EMEM without serum were used as controls. To block non-specific reactive sites, the membranes were immersed in a solution containing $5 \%$ powdered milk
Table 2. Antigenic relatedness among 5 aquareoviruses by cross-neutralization tests. Numbers in bold correspond to the homologous titers

\begin{tabular}{|c|c|c|c|c|c|c|}
\hline $\begin{array}{l}\text { Geno- } \\
\text { group }\end{array}$ & Viral strain & SBR & SCS & $\begin{array}{c}\text { Antiserum } \\
\text { GSV }\end{array}$ & CRV & TRV \\
\hline A & SBR & 7943 & $<10$ & $<10$ & $<10$ & 2512 \\
\hline $\mathrm{B}$ & $\mathrm{SCS}$ & $<10$ & 7080 & 84 & $<10$ & $<10$ \\
\hline C & GSV & $<10$ & $<10$ & 19953 & $<10$ & $<10$ \\
\hline $\mathrm{D}$ & CRV & 199.5 & $<10$ & 94.5 & 5000 & 94.5 \\
\hline$E$ & TRV & $<10$ & $<10$ & 80.2 & $<10$ & 15850 \\
\hline \multicolumn{7}{|c|}{$\begin{array}{l}\text { 'Genogroups as established by Lupiani et al. (1993) } \\
\text { "Neutralization titers expressed as reciprocal of the } 50 \% \text { neutralization } \\
\text { endpoint }\end{array}$} \\
\hline
\end{tabular}

Table 3. Antigenic relatedness among 5 aquareoviruses as determined by cross-immunodot tests. Numbers in bold correspond to the homologous titers

\begin{tabular}{|c|c|c|c|c|c|c|}
\hline \multirow{2}{*}{$\begin{array}{l}\text { Geno- } \\
\text { group }\end{array}$} & \multirow{2}{*}{ Viral strain } & \multirow[b]{2}{*}{ SBR } & \multirow[b]{2}{*}{ SCS } & \multirow{2}{*}{$\begin{array}{c}\text { Antiserum } \\
\text { GSV }\end{array}$} & \multirow[b]{2}{*}{ CRV } & \multirow[b]{2}{*}{ TRV } \\
\hline & & & & & & \\
\hline A & SBR & $10000^{\mathrm{b}}$ & 500 & 1000 & 1000 & 2500 \\
\hline B & SCS & 500 & 10000 & 5000 & 1000 & 1000 \\
\hline C & GSV & 1000 & $<10$ & 25000 & 1000 & 1000 \\
\hline $\mathrm{D}$ & CRV & 500 & $<10$ & 500 & 10000 & 1000 \\
\hline$E$ & TRV & 10 & $<10$ & 1000 & 100 & 25000 \\
\hline \multicolumn{7}{|c|}{$\begin{array}{l}{ }^{a} \text { Genogroups as established by Lupiani et al (1993) } \\
\text { bImmunodot titers, expressed as the reciprocal of the highest dilution of } \\
\text { antisera giving a positive test }\end{array}$} \\
\hline
\end{tabular}


in PBS for 30 min at room temperature and then washed 3 times (10 min each) with PBS containing $0.02 \%$ Tween 20 . The antisera against the 5 aquareoviruses were diluted as described for the former experiment and the membrane was immersed in the respective dilution of each antiserum and incubated at room temperature for $1 \mathrm{~h}$. After washing as above, goat antirabbit IgG conjugated with peroxidase (diluted 1/1000 in PBS) was added and the mixture incubated for $1 \mathrm{~h}$ at room temperature. The membranes were washed and immersed in the colordeveloping solution (30 mg of $1-\mathrm{Cl}-\alpha-$ naphthol dissolved in $1 \mathrm{ml}$ of cold methanol, plus $50 \mathrm{ml}$ of PBS and $30 \mu \mathrm{l}$ of $30 \% \mathrm{H}_{2} \mathrm{O}_{2}$ ). After the appearance of a blue color, which indicates a specific positive reaction, membranes were washed, air dried, and conserved in vacuum sealed plastic bags.

The serological relationships $(1 / r)$ between the aquareoviruses were calculated as described by Archetti \& Horsfall (1950) from the formula $r=\sqrt{r_{1} \times r_{2}}$, where $r_{1}$ and $r_{2}$ are the heterologous titers divided by the homologous titers for the corresponding antisera. A value of $1 / r=1$ between 2 viruses indicates that they are serologically identical, and a value of 2 will indicate that there is a relatedness of $50 \%$. The higher the value, the lower the relatedness.

Results and discussion. Cross-neutralization has been reported by Dopazo et al. (1992) as the most useful procedure to study serological relatedness among aquareoviruses. This assay was therefore chosen for an immunological comparison of viral strains from the 5 genogroups of the genus Aquareovirus. The immunodot assay was employed for comparative purposes.

Titers of antisera against homologous and heterologous viruses obtained by the neutralization and immunodot assays are shown in Tables 2 \& 3, respectively. Homologous titers were high ranging from $1 / 5000$ (for CRV) to $1 / 19953$ (GSV) by neutralization and from $1 / 10000$ (SBR, SCS and CRV) to $1 / 25000$ (GSV and TRV) by immunodot. In a previous report (Dopazo et al. 1992), the aquareoviruses were thought to be poorly immunogenic in rabbits based on the titers of antisera obtained by neutralization (maximum value: 1/7080). The antiserum titers obtained in the present study are remarkably high, which rule out that conclusion. Since in the protocol to obtain antisera, viral purification was modified with respect to previous reports (Dopazo et al. 1992) to avoid use of sonication, mercaptoethanol and deoxicholate, integrity of the virus may have been better maintained, which could explain those higher antisera titers.

Some authors have employed cross-neutralization titers to determine serological relatedness among aquareoviruses (Brady \& Plumb 1988). However, use of cross-neutralization ratios is a better approximation to serological comparisons among viral strains, and these have been employed by many authors (Okamoto et al. 1983, Hedrick et al. 1984, Ishiguru et al. 1984, Dopazo et al. 1992). In the present report, the serological relationship ratios were calculated according to Okamoto et al. (1983) from the antisera titers obtained by crossneutralization and cross-immunodot, and the results are shown in Tables $4 \& 5$.

The ratio value determining that 2 viral strains correspond to 2 different genogroups was established at $>20$ by Jørgensen (1972) based on a decision by the Committee on Enteroviruses in 1962. As shown in Table 3, ratios by cross-neutralization were much higher than 20, clearly demonstrating that the 5 selected aquareovirus strains employed correspond to 5 separate serogroups. Serological ratios calculated from cross-immunodot tests yielded different results. The 
values were not only lower than by neutralization, but also under 20 in 2 cases (serological relatedness of SBR with GSV and CRV). This disparity between results from the 2 techniques could be due to involvement of different epitopes in the antibody-antigen reaction.

In a previous study Dopazo et al. (1992) found some relationship between neutralization ratios and RNA profiles of several aquareovirus strains, and established that cross-neutralization is the best tool for studying serological relatedness among aquareoviruses. The results presented here agree with that conclusion. On the other hand, since the $1 / t$ values are usually lower by immunodot than by neutralization tests, as shown in the present study and in previous reports (Dopazo et al. 1992), perhaps the criterion for determining serogroups by neutralization $(1 / r>20)$ should be changed for immunodot data. Finally, it appears that the serogroups determined by cross-neutralization correlate with the genogroups established by Lupiani et al. (1993); however, further studies including a larger number of aquareovirus strains must be conducted to confirm that conclusion.

Acknowledgements. This work was supported by Grants XUGA 20002A94 from Xunta de Galicia and MAR 89-0270 from the Comisión Interministerial de Ciencia y Tecnología (CICYT), Spain

Responsible Subject Editor: F. M. Hetrick, College Park, Maryland, USA

\section{LITERATURE CITED}

Ahne W, Kölbl O (1987) Occurrence of reovirus in European cyprinid fishes (Tinca tinca Lin.; Leuciscus cephalus Lin.). J Appl Ichthyol 3:139-141

Archetti I, Horsfall FL (1950) Persistent antigenic variation of the influenza A viruses after incomplete neutralization in vivo with heterologous immune serum. J Exp Med 92: $44.1-462$

Brady YJ, Plumb JA (1988) Serological comparison of golden shiner virus, chum salmon virus, reovirus $13 \mathrm{P} 2$ and catfish reovirus. J Fish Dis 11:441-443

Dopazo CP, Toranzo AE, Samal SK, Roberson BS, Baya A, Hetrick FM (1992) Antigenic relationships among rotaviruses isolated from fish. J Fish Dis 15:27-36

Hedrick RP, Rosemark R, Aronstein D, Winton JR, McDowell T. Amend D (1984) Characteristics of a new reovirus from channel catfish (Ictalurus punctatus). J Gen Virol 65: $152 \vec{r}-1534$

Ishiguru S, Izawa H, Kodama H, Onuma M, Mikami T (1984) Serological relationships among five strains of infectious pancreatic necrosis virus. J Fish Dis 7:127-135

Jørgensen PEV (1972) Freund's adjuvants: their influence on the specificity of viral antisera. Acta Pathol Microbiol Scand Sec B 80:931-933

Lupiani B, Hetrick FM, Samal SK (1993) Genetic analysis of aquareoviruses using RNA-RNA blot hybridization. Virology $197: 475-479$

Okamoto N, Sano T, Hedrick RP, Fryer JL (1983) Antigenic relationships of selected strains of infectious pancreatic necrosis virus and European eel virus. J Fish Dis 6:19-25

Reed LJ, Müench H (1938) A simple method of estimating fifty percent endpoints. Am J Hyg 27:493-497

Manuscript first received: January 16, 1996

Revised version accepted: May 21, 1996

\section{Erratum}

\section{Re: L. Margolis, M. L. Kent, P. Bustos}

"Diseases of salmonids resembling myxosporean whirling disease, and the absence of Myxobolus cerebralis, in South America"

\section{Dis Aquat Org 25: 33-37 (1996)}

- An error occurred in the first author's initials. The correct form is given above 